\title{
RESISTANCE IS FERTILE - OM OVERVÅGNINGENS OLIGOPTISKE BLIK
}

Overvågningen af Danmarks borgere begynder straks efter fødslen. I det øjeblik hvor den nyfødte borger udstyres med et CPR-nummer bliver det muligt for staten og andre instanser kan kontrollere og gribe ind på mange måder i dennes livsforløb. Overvågningen kan endog siges at starte langt tidligere, når det ufødte barns velbefindende regelmæssigt kontrolleres af sundhedssystemet, og det blandt andet screenes for uønskede sygdomme. Overvågning optræder samtidig i adskillige sammenhænge på tværs af borgernes liv: fra videoovervågning, fartkontrol og logning af internettrafik til paskontrol i lufthavne og registrering af købsmønstre i supermarkeder. Mange deltager endog 'frivilligt' i overvågningen af sig selv og andre, når de benytter sociale netværkstjenester såsom Facebook. Overvågning kan således betragtes som et - i mange henseender - gennemtrængende fænomen i samtiden.

Mediekunstneren Jill Magids performative objekt "Surveillance Shoe | Legoland" (Magid) er tilsyneladende et eksempel på en konkret iscenesættelse af en sådan penetrerende og allestedsnærværende overvågning. Objektet er en højhælet damesko, som har fået påmonteret videoovervågningsudstyr, der kigger op ad performerens ben. Man ser dermed verden fra et ekstremt frøperspektiv, hvor underbenet (og ofte lår og skød) er i konstant fokus.

Magids objekt er et eksempel på, at overvågningspraksisser og deres udtryk også er et kunstnerisk og æstetisk udgangspunkt for samtidskunsten.

I denne artikel vil vi analysere Magids videoovervågningssko med særligt fokus på objektets iboende problematisering af overvågningens komposition, rækkevidde og effekter. Det vil vi gøre ved at sætte det i dialog med aktør-netværksteoretikeren Bruno Latours begreb 'oligoptikon' (Latour; Latour og Hermant), med hvilket 'overvågning' betragtes som en effekt af en specifik komposition af socio-tekniske aktører og deres sampil. Oligoptikon-begrebet er udviklet i kritisk dialog med Foucaults begreb 'panoptikon', som han anvendte på divergerende og meget nuancerede måder. Efterhånden er 'panoptikon' imidlertid blevet transformeret, så det nærmest er kommet til at henvise til en universel struktur - en slags 'funktionel maskine', der altid har samme effekt på tværs af overvågningssituationer. Latours begreb om oligoptikon tilstræber en tilbagevenden til nuancerne gennem undersøgelse af, hvordan specifikke kompositioner af socio-tekniske aktører danner partikulære overvågningssituationer, hvor den enkelte overvåger (blandt mange forskellige 


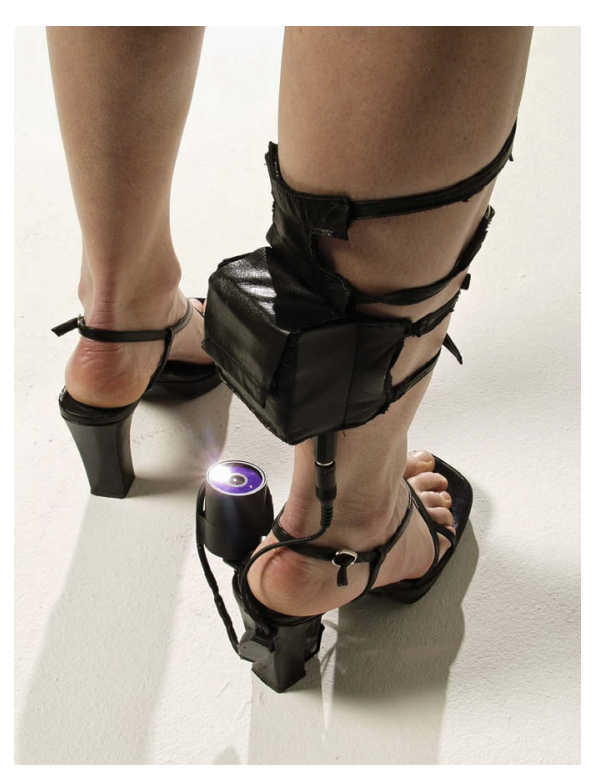

Figur 1: Fod med sko. "Surveillance Shoe | Legoland", 2000. Shoe: High heals, IR surveillance camera, battery pack, wireless transmitter in shoe sole. Video: B/W footage produced by Surveillance Shoe. 6 min. () Jill Magid. Courtesy of the artist and Yvon Lambert Paris, New York.
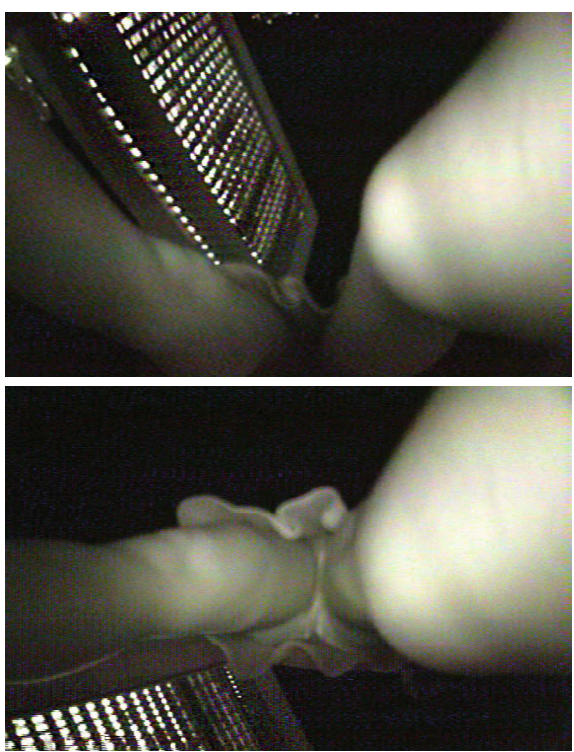

Figur 2: Billedet fra skoens kamera, når performeren går. "Surveillance Shoe | Legoland", 2000. Shoe: High heals, IR surveillance camera, battery pack, wireless transmitter in shoe sole. Video: B/W footage produced by Surveillance Shoe. 6 min. (C) Jill Magid. Courtesy of the artist and Yvon Lambert Paris, New York.

overvågere) kan se meget præcist, men med et skrøbeligt blik. Dette komponerede blik har to vigtige karakteristika: det fungerer for det første som medproducent af virkeligheden, og for det andet er den virkelighed, som produceres (og dermed den verden, der overvåges), afgrænset og partikulær. Vi har altså at gøre med en situation af multiple, og delvist forbundne virkeligheder $(\mathrm{Mol})$, hvorfor det ikke giver mening at vurdere konkrete overvågningsfænomener ud fra en universel overvågningsmodel.

Snarere end at søge at forklare overvågning generelt - nu blot på en ny måde peger oligoptikonbegrebet i stedet på behovet for at følge, hvordan partikulære virkeligheder opstår, bygges, skabes og vedligeholdes. Dermed peges der også på behovet for større empirisk sensitivitet. Oligoptikonbegrebet er således et generisk og ikke et generelt koncept, der tager udgangspunkt i sagen selv og i, at vi ikke på forhånd kan afgøre eller definere, hvad de afgørende forhold i en overvågningssituation er, før denne er undersøgt og analyseret. (Gad og Lauritsen; Gad og Jensen "On the Consequences of Post-Ant.")

På basis af Latours begreb og Magids kunstobjekt vil vi i det følgende argumentere for, at overvågningsfænomener kan begrebsliggøres som 'oligoptiske kom- 
positioner'. Både Magids objekt og Latours oligoptikon insisterer på, at bestemte overvågningsfænomener har en særlig og en afgrænset karakter, og de angiver dermed nødvendigheden af at tilgå overvågning som en mangfoldighed af specifikke situationer og fænomener.

Dette peger ikke mindst på, at partikulære former for modstand, som den vi finder udtrykt i "Surveillance Shoe | Legoland", synes mere frugtbare end en generel kritik af overvågning 'som sådan'. Oligoptikon-begrebet og Magids objekt peger samstemmende på, at generaliserede forestillinger om overvågning, der stadig har deres tag i os og danner baggrund for både dystopisk angst og utopisk jubel, løbende må bearbejdes.

\section{Udfordringen af traditionelle overvågningsforståelser}

Spørgsmålet er, om der overhovedet findes et livsområde, som i dag kan undslippe overvågningens blik? Ud fra en generel betragtning og i forlængelse af vores indledning er svaret et klokkeklart 'nej', og umiddelbart bidrager Magids objekt som sagt til netop dette svar. Men som vi vil vise her, er objektet samtidig ét blandt mange tegn på, at de fænomener, vi aktuelt vælger at betegne "overvågning”, udgør en broget og mangeartet forsamling. Overvågningsfænomenernes udbredelse og den forskellighed, der fremtræder, når man undersøger dem nærmere, er præcis det, der, ifølge overvågningsforskeren Kevin Haggerty, bør gøre os mistænksomme over for forestillingen om at udvikle "en anvendelig model for overvågning, som kan gøres generel nok til at dække et nævneværdigt antal overvågningskontekster” (Haggerty 39).

Haggertys udsagn indgår i en debat, som har trængt sig på i forskningsfeltet 'overvågningsstudier' (Lyon). Med udgangspunkt i en tværfaglig, men primært sociologisk, fagtradition har overvågningsstudierne været præget af en ambition om at udvikle et kritisk begrebsrepertoire bl.a. med henblik på at nuancere offentlighedens billede af overvågning. I en tid, hvor overvågning synes at udbrede sig med en grad og hastighed, som burde muliggøre, at forskningsfeltet kunne konsolidere sig, viser det sig imidlertid, at de begreber, man hidtil har benyttet, ofte er for generelle og dermed upræcise i forhold til at forstå konkret og mangeartet overvågning.

Årsagen kan være, at feltet indtil for ganske nylig har været domineret af nogle få metaforer - navnlig brødrene Benthams idé om panoptikon, som blev gjort berømt af Foucault (Foucault), og George Orwells idé om 'Big Brother' fra romanen "1984” (Orwell). Forestillingerne har fungeret som en slags idealtyper af overvågning og konnoterer primært konsekvenser som (totalt) overblik, kontrol og (selv)disciplinering (Gad and Lauritsen). I den offentlige debat trækker modstandere af overvågning på konnotationer til de to idealtyper og angiver dem som dystopiske endemål, mens tilhængere af overvågning nedtoner problemet og sætter fokus på overvågningens mere positivt ladede aspekter som sikkerhed og tryghed. Begge fløje tager dog som hovedregel udgangspunkt i en bekræftelse af idealtyperne, og dermed i en forståelse af, at man med sikkerhed kan vide noget generelt om overvågningens effekter. 

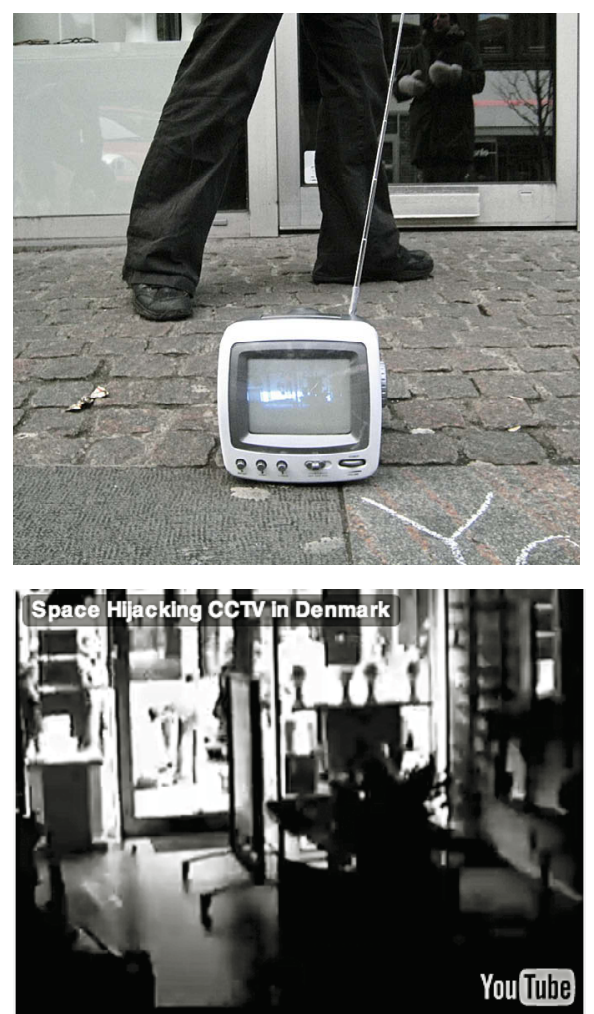

Figur 3: Billeder fra performancen

“Hijacking CCTV”, Århus, feb 2008.

Vi ser det i Synoptik monterede

overvågningskameras billed-feed på hhv. et lille tv, der er opstillet på gaden og

på YouTube, hvor kunstnerkollektiverne efterfølgende oploadede optagelse af det opsnappede feed.
Samme tendens finder vi i populærkulturen (Gad og Hansen) og i kunsten, hvor de fleste kunstneriske bearbejdelser tager udgangspunkt i idealtyperne, når de kritiserer den stigende overvågning og problematiserer vores manglende viden om og kontrol med de informationer, der genereres igennem overvågningssystemerne. Kunstnerkollektiverne Leipziger Kamera (Leipziger Kamera) og Space Hijackers (Space Hijackers) er eksempler herpå: I det interventionistiske værk "HiJacking CCTV" (se figur 3), som grupperne har skabt i fællesskab, tager de udgangspunkt i de overvågningsstrukturer, som de ser overvågningskameraerne manifestere.

I "HiJacking CCTV" bevæger performerne sig gennem det offentlige rum, mens de med hjemmelavet teknologi opsnapper og interfererer i det signal, som trådløse overvågningskameraer sender til den modtagende monitor (Leipziger Kamera og Space Hijackers). Performerne kan således dokumentere, hvad det ellers utilgængelige kamera ser, og vise det for dem, som kameraet peger på, men de kan modsat også sende et billedsignal til monitoren ved at 'overdøve’ det signal, som kameraet sender, og således vise den, der betragter monitoren, et alternativt billede. Værket

forskyder på den måde overvågningsblikket fra betragteren til den betragtede og peger med sin offentlige afsløring af de overvågende kameraers billede bogstaveligt talt på, at overvågning er grænseløs og trænger ind alle vegne.

Evnen til at interferere indgår også i Jill Magids "Surveillance Shoe | Legoland", hvor skoen indeholder en lille trådløs sender, der muliggør, at skoens optagelser kan ende på den monitor, hvor det ellers er meningen, at et fast installeret overvågningskameras billede skulle vises. Sammenfaldet mellem de to værker virker umiddelbart stort, idet Magid tilsyneladende også problematiserer den stigende overvågning i nutidens samfund ved at vende overvågningskameraet mod de mest private dele af den kvindelige krop og sende dette signal ud i verden. Vi har fuld adgang til at kigge op under skørtet, og kroppens mest intime dele rammes af 
kameraets afslørende og gennemborende blik - intet er for privat for kameraet, og alt kan og vil blive afsløret.

Der er dog afgørende forskelle på "HiJacking CCTV” og "Surveillance Shoe | Legoland", for overvågningsskoen har ikke til formål at forstyrre et allestedsnærværende overvågningsblik. I stedet for at være et kritisk indspil på linje med "HiJacking CCTV", kan "Surveillance Shoe | Legoland” snarere forstås som et værk, der tematiserer overvågning som en afgrænset 'komposition'. Kameraet opererer på den ene side tilsyneladende uden grænser for sin indtrængen (det peger på performerens mest intime dele), og på den anden side har det kun adgang til en særlig virkelighed, som værket medkomponerer - og det oven i købet på en meget fastlåst måde (i kraft af kameraets position på foden). Vi kan dermed ikke forstå værket på tilstrækkelig nuanceret vis, hvis vi blot holder os til de idealtypiske metaforer, fordi de netop er baseret på en forestilling om, at alt ses, overskues og kontrolleres fra et centralt sted.

Idéen, om at overvågningen har en central kilde, bidrager til en forestilling om, at vi kan bedømme, hvilke effekter overvågningen generelt har, og det er netop denne generaliserende tendens, som er genstand for Haggertys ovenfor citerede kritik. Denne kritik bekræftes af værker som "Surveillance Shoe | Legoland". Hermed er deres samstemmende udsagn, at overvågningsstudier bør forlade tanken om at forstå overvågning som et generalisérbart fænomen, der lader sig beskrive i lyset af idealtyperne. I stedet bør vi lede efter andre analytiske ressourcer, der tillader, at vi kan forstå overvågning som et nuanceret, specifikt og situeret fænomen. Latours begreb 'oligoptikon' er netop et sådant bud på en alternativ konceptualisering af overvågningens karakter, og i det følgende vil vi beskrive udvalgte aspekter af begrebet med henblik på efterfølgende at lade Jill Magids overvågningssko indgå i dialog hermed.

\section{Det oligoptiske blik}

Begrebet oligoptikon (fra græsk oligoi (få) og optikos (syn)) er hos Latour først og fremmest et metodologisk sensitiverende begreb rettet mod at skabe en større åbenhed i forsøgene på at forstå konkrete overvågningsfænomener. I sagens natur definerer Latour derfor ikke begrebet entydigt, men benytter det i stedet til at associere empiriske eksempler til en række vigtige analytiske temaer.

Oligoptikonbegrebet udvikles særligt på baggrund af Latours og fotografen Emilie Hermants studier af en række overvågende institutioner i Paris og fremstilles i bogen "Paris, invisible city" (Latour og Hermant). Ifølge Latour besidder institutionerne, trods deres minutiøse overvågning, hverken hver for sig eller samlet den panoptiske kraft til at disciplinere alle, endsige Big Brothers evne til at se alt, at være alle steder og at konvergere i et center. Snarere finder vi i Paris en række specifikke, overvågende instanser, der servicerer og muliggør en række forskellige, delvist krydsende, men aldrig totalt overlappende sociale flows i byen. Og det er netop den delvise og specifikke overvågning, der bevirker, at instanserne overhovedet 
kan handle, idet de gennem overvågningen hver især konstruerer en afgrænset og præcis viden om dele af den parisiske virkelighed. Ja, faktisk medkomponerer de hvert deres 'eget' 'Paris':

"I hvert tilfælde indfanger oligoptika forskellige materielle substanser, forskellige aggregater, forskellige væremåder, forskellige fysikker. Men disse aggregater er ikke indlejret i en fælles materiel substans, hvoraf hvert af dem så kunne siges at erobre et aspekt” (Latour og Hermant 79).

Latour og Hermant besøger således en lang række steder, hvor virkeligheden konstrueres i kraft af et bestemt slags 'overblik' over Paris. De forskellige positioner og 'blik' fanger ikke forskellige aspekter af det samme Paris, men medproducerer disse 'aspekter' - og dermed deres egen version af Paris - uden på noget tidspunkt at konvergere eller ende i et totalt overblik. Hvert enkelt blik kan nemlig kun se noget specifikt og kan dermed kun konstruere sin 'virkelighed' ved i samme ombæring at udelukke det meste af Paris fra sit synsfelt.

"Vand, elektricitet, telefoni, trafik, meteorologi, geografi, byplanlægning: alle har de deres oligoptikon, et kæmpe kontrolpanel i et aflukket kontrolrum. Herfra kan man på alle tidspunkter se meget lidt, men alt optræder meget præcist [...] Ingen af disse kontrolrum eller synoptiske paneler sammenføjer alle [byens] flows på ét sted på noget som helst tidspunkt [...] Intet fugleperspektiv kan med blot ét blik indfange stedernes multiplicitet, som tilsammen udgør Paris som helhed. Der findes hverken panoptika eller panoramaer, der findes kun farverige dioramaer med multiple forbindelser, ledninger på kryds og tværs under veje og fortove, langs metroens tunneler, på toppen af kloakrør”. (Latour og Hermant 32).

Et oligoptikons effektivitet er altså uløseligt forbundet med dets proportionelle blindhed (Latour og Hermant 28). Det er netop kun ved at konstruere en meget specifik viden, at oligoptika kan bidrage til at holde liv i byens flows; deres funktion er at fastholde en dynamisk middeltemperatur og forhindre, at byen koger over. Oligoptika gør planlægning mulig, men 'fastfryser' ikke byen med deres blikke.

Konkret starter et oligoptikon ifølge Latour altid med et bestemt rum, et bureaukratisk kontor, et laboratorium, et observatorium eller en anden form for 'kontrolrum', hvor der indsamles og behandles data, laves plancher, kategoriseres, og hvor forskellige typer input af information transformeres. Det er kun i kraft af transformationer af information, at vandselskabet eksempelvis kan træffe beslutning om at øge vandforsyningen i Paris på bestemte tidspunkter, f.eks. i pausen i fodboldfinalen, hvor store dele af Paris trækker ud i toilettet på omtrent samme tid.

Et eksempel på et oligoptikon, som deltager i dette flow af transformationer, er et kontor på et universitet i Paris, hvor frøken Baysal styrer lokalernes allokering til undervisning. På en måde ved hun alt om universitetet og har et godt overblik, men Latour observerer polemisk, at hvis man forsøger at kigge ud ad hendes vindue og 
derved søger at danne sig et samlet overblik, så kan man ikke se noget som helst. Hvis man vil se noget, der giver mening, må man helt afstå fra at forsøge på at kigge ud over hele universitetet. For i samme øjeblik man kigger ud ad vinduet, bliver man simpelt hen begrænset til sit eget perspektiv, i den forstand at perspektivet lukker sig om sig selv og ikke kan forbindes til kæden af transformationer. For at undgå denne absolutte begrænsning må man inddrage en række artefakter, udregninger og opsummeringer som en slags 'spor' efter andre ting i omgivelserne. Tilsammen komponeres på den måde et oligoptikon. Overblikket findes altså på kontoret, men det er en helt bestemt type overblik: det er delvist, afgrænset og forbundet.

"Det, jeg ser, ser jeg ikke, medmindre jeg undlader at kigge udenfor, for så bliver jeg med det samme begrænset til mit eget synspunkt. [Man må derfor] skelne mellem personer, som kigger ud ad et vindue og ikke ser noget som helst, som ingen idé har om, hvem de er, eller hvad de skal gøre, fra de personer, som befinder sig $i$ et kontinuert flow af spor, som samler et billede op, der både lærer dem noget om, hvem de er, og om den globale ramme, i hvilken de skulle være situeret. Enten kigger jeg, bogstaveligt talt, og ser ingenting, jeg er ingenting, og ellers ser jeg intet direkte, men jeg betragter et spor og begynder dermed at se noget, jeg bliver gradvist til nogen”. (Latour and Hermant 11).

Grunden, til at frøken Baysal kan se præcist, kan blive 'nogen', en 'ekspert' og en 'central person' i driften af universitetet, er netop, at hun ikke kigger ud ad vinduet, men drejer blikket ind i sit oligoptikon, mod registreringerne, tabellerne og computerskærmen.

Platon tog således fejl ifølge Latour. Frøken Baysal kan kun handle i forhold til universitetet ved at sidde inde i 'hulen' - kun i kontrolrummet bliver skolen, dens brugere, dens tid og rum synlige samtidigt. Men det betyder ikke, at det, der foregår i et oligoptikon, er en illusion, eller at man i kontrolrummet er adskilt fra 'den virkelige verden'. Snarere tog Platon, ifølge Latour, også fejl i at adskille idéernes rige fra den materielle verden. For i frøken Baysals praksis, og i andre oligoptika, gælder det, at "vi aldrig forlader 'det virkelige' til fordel for 'det formelle', vi glider altid fra noget til noget andet virkeligt” (Latour og Hermant 26). Den måde, som Baysal har overblik på, skal dermed ikke forstås som et resultat af en formfuldendt repræsentation af virkeligheden i traditionel forstand. Snarere er hendes specifikke overblik et resultat af de cirkulerende referencer og relationer, der etableres mellem hendes kontor, tidstabellerne, undervisningslokalernes dørskilte, mv.

Et oligoptikon som frøken Baysals producerer således ikke det panorama, som ville tilfredsstille panoptikon-inspektøren eller Big Brother, men snarere et 'diorama', som er en konkret miniaturemodel - en skrumpet re-præsentation eller en gen-præsentation. For at kunne transformere information og kunne handle på noget af Paris, skal et udsnit først 'skrumpes' til en model, en statistik, et kort etc. Disse 'repræsentationer' sameksisterer som præsentationer af Paris, og kan endda gøre det i fuld fordragelighed, for som Latour påpeger, så kan referenceformer 
sameksistere uden nogensinde at blive sammenblandet. Dette skyldes, at der ikke findes nogen 'egentlig virkelighed', som kan refereres til. I stedet for at forestille sig en verden, der eksisterer uafhængigt af vores perspektiv, og som vi derfor kan zoome ind og ud på og lave mere eller mindre præcise repræsentationer af, skabes virkeligheden i oligoptika i 'transformative zooms', og alle perspektiver er komponeret i kraft af de forbindelser, som de indgår i med deres omgivelser.

Et transformativt zoom omkonfigurerer og komponerer en virkelighed og et perspektiv. Et oligoptikon producerer og indeholder dermed sin egen skala; det sameksisterer med andre oligoptika, men de konvergerer ikke, for de relaterer ikke til en universel skala. Dermed forstyrrer ethvert oligoptikon en udbredt forestilling om eksistensen af en almengyldig eller 'normal' proportionssans - det indeholder nemlig helt sin egen.

Et meget centralt element i Jill Magids "Surveillance shoe | Legoland" er netop også en forstyrrelse af vores normale proportionssans. Objektet fremviser, at en bestemt form for overvågning 'leveres' med sine egne indbyggede skalaer og sine egne midtpunkter og begrænsninger. I den følgende analyse af Magids objekt vil vi derfor særligt lade os inspirere af Latours tanker om et oligoptikons proportionssans, dets transformative kraft og de perspektiver, som det (med)producerer.

\section{Om "Surveillance Shoe | Legoland"}

I "Surveillance Shoe | Legoland" ser man som sagt (og som vist i (figur 2)) verden fra et ekstremt frøperspektiv, hvor det visuelle fikspunkt er underbenet (og dermed ikke mindst lår og skød). Værket giver således god mulighed for, at man hurtigt kan drage konklusionen, at man med dette specifikke overvågningskamera og denne specifikke overvågningssituation får adgang til at holde øje med et meget privat anliggende. Vi kan hele tiden bogstaveligt talt se, hvad der foregår mellem performerens ben, og intet skjules for os. Overvågningsskoen indbyder derfor umiddelbart til en kønsanalyse, som kan kobles nærmest gnidningsfrit til overvågningens idealtyper: Én analytisk vinkel kunne da være, at den højhælede sko som fetishobjekt italesætter et maskulint blik på den feminine krop, som dernæst forstærkes flerfold af det påmonterede kamera. Et maskulint blik som i det hele taget kan siges at have fundet sin ultimative manifestation i overvågningskameraet, hvorfra verden kan overskues og betragtes nøgternt, ingen betragtede kan undslippe, og alle må som konsekvens heraf underkaste sig både kameraets konkrete blik og den bagvedliggende lov og orden. Kameraet på Magids sko kan derfor ved første øjekast forstås som den logiske efterfølger til værker som "HiJacking CCTV", fordi skoens kamera 'går hele vejen' og holder øje med 'mandens ejendom', kvindens skød, fra sit panoptiske centrum, så hun som konsekvens heraf frivilligt underkaster sig selvdisciplineringens logik.

Men samtidig bliver det også hurtigt klart, at denne konklusion ikke kan drages alligevel. For selvom kameraet tilsyneladende har den overvågede krop som midtpunkt, og selvom kroppen tilsyneladende ikke kan undslippe denne overvågning, 
er det alligevel kroppen, der bestemmer kameraets blik. Tilslutningspunktet, foden, er så bevægeligt, at vi - lige så let som at sige, at vi kan se alt - kan sige, at vi ikke kan se noget som helst. Og kameraets blik er bundet til fodens position, så performeren kan så let som ingenting undslippe overvågningens 'diktatur' ved at bøje benet og således sende betragterens blik ud i verden i stedet for ind under sit skørt.

Det særlige ved den overvågning, som foregår i "Surveillance Shoe | Legoland”, kan således bedst beskrives som noget, der på den ene side ser 'alt', men på den anden side ikke ser ret meget, og dermed byder objektet sig snarere til

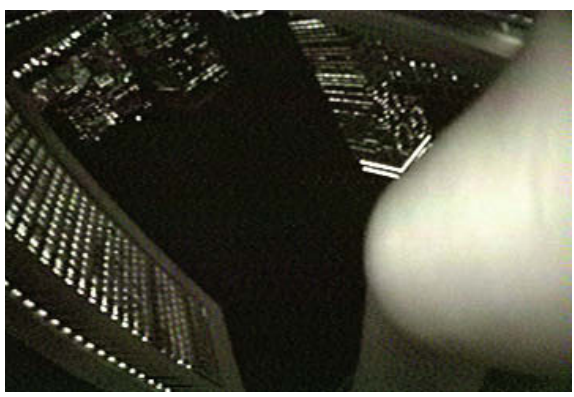

Figur 4: Billedet fra skoens kamera når performeren bøjer benet. "Surveillance Shoe | Legoland", 2000. Shoe: High heals, IR surveillance camera, battery pack, wireless transmitter in shoe sole. Video: B/W footage produced by Surveillance Shoe. 6 min. (c) Jill Magid. Courtesy of the artist and Yvon Lambert Paris, New York. som en oplagt dialogpartner til oligoptikonbegrebet.

På linje med oligoptikon, kan "Surveillance Shoe | Legoland” læses som et kritisk indspil i debatten om selve muligheden for en altpenetrerende og allestedsnærværende overvågning. Snarere end blot at fremvise (betydningen af) en generel overvågningstendens arbejder Magids objekt med at afsøge og iscenesætte overvågningens muligheder og grænser, og det fremhæver gennem sin kunstneriske afsøgning desuden, hvordan idéen om det altpenetrerende og centralperspektiviske overvågningsblik nødvendigvis må lide sammenbrud. Med sit ekstreme perspektiv (fokus op ad indersiden af benet til skødet) og sin bevægelige base (foden), unders $\varnothing$ ger objektet nemlig også overvågningen som fænomen og peger - ligesom Latour og Hermants oligoptikon-undersøgelser - på, at 'minutiøse aspekter' og den materielle gestaltning af overvågning er afgørende for dens kraft og rækkevidde, og at begge dermed må inddrages i undersøgelsen deraf. Vi vil nu se nærmere på, hvordan værket kan siges at have de for oligoptikon-begrebet centrale aspekter skala, perspektiv og transformation som fundament for sit udtryk.

Det mest dominerende element i stillbillederne fra skoens overvågningskamera er performerens ben, som imidlertid ikke er i fokus rent fototeknisk set (se figur 2). Benet fylder mest i billedfladen og fremstår stort og hvidt, men det fremstår også ude af fokus og dermed en smule drømmeagtigt, hvor bygningerne står klart. Billederne viser verden set fra jordoverfladen og derfor også 'på hovedet': bygningerne vokser nærmest ud af billedets øvre kant, og som beskuer drejer man umærkeligt hovedet for at få bygningerne til at 'vende rigtigt' i billedet, omend det så fører til, at benet vender forkert. Den fornemmelse forstærkes af, at perspektivet er forskruet grundet den ekstreme vidvinkel, og benet derfor virker til at være mange gange større end skyskraberne. Og idet billedets kompositoriske forsvindingspunkt ty- 
pisk er kvindens skød og ikke et fjerntliggende punkt $\mathrm{i}$ horisonten, bliver forholdet mellem skyskrabere og ben ikke udlignet af centralperspektivets skalaforståelse. Skalaen, hvorudfra vi forstår forholdet mellem billedets enkeltelementer, er således ikke den samme, som et 'normalt' centralperspektivisk billede anvender, hvilket betyder, at man som tilskuer perceptivt kæmper med at få de mange perspektiver til at stemme overens med den verden, vi kender, sådan at oppe er oppe, nede er nede og skyskrabere er større end ben.

Stillbillederne giver imidlertid et ganske andet indtryk end filmen selv: På filmen vælter verden rundt og er $i$ konstant bevægelse fra top til bund og fra side til side, idet kameraets position er bevægelig, da dens basis, foden, er i gang med at gå. Det mest stabile element inden for filmens ramme er således performerens ene underben, mens det andet ben og ikke mindst omgivelserne kun kan tilgås i flygtig, fragmenteret og dermed uoverskuelig form. Underbenets faste position giver samtidig en slags Verfremdungs-effekt, fordi det på den ene side virker helt normalt, men samtidig helt forkert, dels fordi det fremstår uskarpt, og dels fordi vi ikke er vant til at se gående ben, der er statiske, og statiske omgivelser, der er i konstant bevægelse. Så vi ser tilsyneladende kun klart og 'forståeligt', hvis vi fryser billedet og betragter videofilmen billede for billede. Normalt vil man i levende billeder netop have fordel af tidsligheden, fordi man i forløbet over tid får afklaring på de handlinger, som hvert billedelement foretager inden for billedfeltet. Stillbilleder bliver på den måde netop fastfrosne tidsbilleder, som peger på den mening, der skabes, når de ses i sammenhæng med andre af filmens billeder. I "Surveillance Shoe | Legoland" forholder det sig anderledes - her er det tilsyneladende det fastfrosne billede, som giver mest information fra sig, mens selve filmen fremstår nærmest uendeligt forvirrende. Vi mister umiddelbart enhver form for overblik, når vi ser outputtet fra overvågningsskoen som levende billeder, hvilket værkets følgetekst siger, vi skal (den er gengivet ordret i billedteksten til figur 1, 2 og 4).

Men netop når man sammenligner filmen med det fastfrosne billede, ser man, at værket som konsekvens af de to modi indeholder en kritik af sig selv. Det tilsyneladende overblik på stillbillederne fungerer nemlig som parallel til det, som Latour betegner som den panoptiske fastfrysning af perspektiver: Billederne fremstår fastfrosne og med overblik, mens filmen fastholder det transformative flow, hvor man bevæger sig rundt $i$ en situation, og hvor der er interaktion mellem de forskellige elementer $\mathrm{i}$ overvågningssituationen. Filmen viser dermed netop, at man, når man betragter filmen i stillbilleder, bliver fastlåst i netop et perspektiv. Det føles ganske vist, som om blikket først bliver effektivt, når det fastfryses, men filmens kaotiske forløb viser netop, at denne effektivitet så at sige er på skrømt og tilsyneladende. Værket fremviser således den panoptiske tendens, men i samme åndedrag bliver tendensen genstand for kritik, fordi det viser sig, at blikket ikke kan fast- og opretholdes.

Sammenfattende kan "Surveillance Shoe | Legoland" siges at italesætte og fremvise et udsagn om overvågning som sådan - om overvågningens oligoptiske 'natur' - idet værket tydeligvis arbejder med overvågningens form og grænser; vi får adgang til at se noget og ikke noget andet, og det, vi ser, ser vi på en meget bestemt 
måde. Ligesom med Latours oligoptikon-begreb er den generelle pointe, at overvågningsfænomener må forstås som særlige og afgrænsede, men stadig effektive 'kompositioner'. Disse kompositioner er hverken hver for sig eller samlet i stand til at danne et centralt og alvidende perspektiv, men derimod udgør de partikulære og delvist forbundne størrelser.

\section{Oligoptikon som modgift til generaliserende tendenser}

I lighed med Latours oligoptikon, fremviser "Surveillance Shoe | Legoland" altså, at overvågning og analyser heraf langt fra blot handler om at identificere mere eller mindre effektive udgaver af 'den samme' panoptiske maskine. Latour argumenterer eksplicit for, at hvis vi kigger nærmere på, hvad der er på spil i den enkelte overvågningssituation, så udviskes muligheden for at kunne forklare overvågning ud fra sådanne modeller hurtigt.

Overvågning er på den måde ikke et generalisérbart fænomen, selvom det ofte kan se sådan ud, og den indsigt angiver én måde, som man kan forstå ordet "Legoland" på, hvis man forstår titlen som en henvisning til forlystelsesparkskonceptet Legoland. Igen er der her tale om, at værket indeholder en kritik af sit eget fundament: på den ene side peger det på, at ligesom forlystelsesparken indeholder nøjagtige miniaturekopier af konkrete steder, så viser også overvågningen af kvindens skød, hvordan der nøjagtigt ser ud i skødets og benets verden. Billeder lyver ikke, som man siger. Men på den anden side peger titlen i samspil med værkets udtryk på, at det, vi ser, blot er en simpel model, som på ingen måde kan forveksles med verdens multiperspektiviske virkelighed. Det, vi ser, er en fin om end meget forsimplet repræsentation af noget meget komplekst, men vi ser bare ikke ret nuanceret, hvis vi insisterer på, at verden kan generaliseres. Så én fortolkning af titlen "Legoland" kunne være, at den peger på, at selvom vi kan genkende verden, så er der ikke desto mindre tale om en stærkt forsimplet model. Lidt på samme måde som Latour med oligoptikonbegrebet påpeger, at det er nødvendigt at distancere sig fra overdrevent generaliserede kategoriseringer for i stedet at følge, forstå og forbinde sig til de multiple virkeligheder, som de mange forskellige oligoptika medproducerer.

Begrebet indgår dermed i et opgør med et fokus på teori og model, som ifølge Latour har præget meget traditionel tænkning, herunder både traditionel sociologi og filosofi, hvor observationer og/eller analyse af konkrete empiriske eksempler, nok betragtes som væsentlige, men til stadighed bliver underordnet en generel kategoriseringsbestræbelse og -interesse (Gad og Jensen "Philosophy of Technology as Empirical Philosophy”). Problemet er, at når man på den måde fokuserer på model, teori og struktur, medfører det en blindhed over for, at verden omkring os hele tiden er under ombygning og transformation. I forhold til sociologien har dette fokus desværre bevirket, at evnen til hele tiden at undre sig over og stille spørgsmål til, hvordan så mange af os kan eksistere sammen, er blevet stærkt svækket. (Latour og Hermant 5-6).

Latour mener altså, at udfordringen er at stoppe med at forlade os på generelle 
modeller som dem, der ofte bygges op om filosofiske kategorier, klasse, køn eller 'sociale strukturer'. I stedet bør man følge de mange spor, som mangeartede aktører efterlader sig i deres konstante arbejde med at bygge samfund. I lyset af kunstobjekter som "Surveillance Shoe | Legoland" kunne man videreføre Latours argument med, at store dele af den akademiske, analytiske tilgang til verden til en vis grad ville kunne skele til kunstens og kunstvidenskabens verden. Her er det nemlig netop en pointe, at den mest interessante forskning og de mest interessante værker er dem, der behandler konkrete koncepter og problemstillinger på en måde, hvor det anlagte perspektiv bibeholder sensitivitet for komplekse modstillinger. Dermed fører de an $i$ en form for frugtbar og subtil modstand mod en given problemstilling frem for at udspy bombastiske og generaliserede udsagn derom.

\section{Konklusion}

"Megalomaner forveksler kortet og landskabet og tror, at de kan dominere hele Paris, bare fordi hele Paris befinder sig foran deres øjne. De paranoide forveksler landskabet med kortet og tror, de bliver domineret, observeret og beskuet, blot fordi en blind person kigger halvhjertet på nogle utydelige tegn på et hemmeligt sted i et rum på fire gange otte meter”. (Latour og Hermant 28).

Tiltrækningen ved den modstand, som tilbydes i kunstobjekter som "HiJacking CCTV" er stor: Kunstnernes performative fremvisning af overvågningen i nutidens samfund spiller på kraftfulde kulturelle forståelser af personlig frihed og personligt handlerum. Og set i det lys rammer kunstnerne bag - i lighed med andre kunstnere, der arbejder ud fra samme udgangspunkt (Hansen) - plet med deres karakteristik. Men som Jill Magids "Surveillance Shoe | Legoland” lige så kraftfuldt påpeger, så er den enkelte overvågningssituation altid fastlåst i sit eget, stærkt begrænsede perspektiv. Derfor har vi i artiklen her ikke tilgået Magids objekt som en 'simpel' kunstnerisk problematisering af nutidens overvågningstendens eller som den potentielle opkomst af en altdominerende magtstruktur. Netop dette objekt tilbyder nemlig mere end en kritik af overvågning 'som sådan'. Det tilbyder snarere et alternativ til, hvordan man kan konceptualisere, analysere og forstå overvågning og overvågningens effekter.

Oligoptikon-begrebet og Magids værk understreger begge, at man i overvågning ser med et meget præcist, men samtidig meget skrøbeligt blik. Dette komponerede blik medproducerer for det første virkeligheden, og for det andet er den virkelighed, som produceres (og altså dermed den verden, der overvåges), afgrænset og partikulær. Dette tydeliggør, at etableringen af ethvert overvågningsblik altid er tilknyttet både et tab og en gevinst. Vi bliver i stand til at se noget og til at handle, men vi bliver samtidig blinde for det meste andet.

Konsekvensen af at tænke i oligoptika, snarere end med panoptikon- og Big Brother-metaforerne, er dermed, at man 'taber' både de dystopiske og de utopiske måder at forestille sig overvågningens rækkevidde og konsekvenser på. Overvågning vil simpelthen ikke længere automatisk få det til at løbe koldt ned ad ryggen på folk: 
"Vi vil helt sikkert miste den megalomanes og den paranoides perverterede lystfølelse, men dette tab vil blive opvejet af gevinsten" (Latour and Hermant 28). Når den altomfattende forklaringsmodel forsvinder, mister man ganske enkelt smagen for den generelle og hurtige kritik af overvågning som sådan. Denne kan nemlig siges at bygge på ideen om muligheden for at realisere et 'fuldkomment perspektiv'. Det er det, Latour polemisk diagnosticerer i citatet, der indleder denne konklusion, idet han angiver, at de mest udbredte forestillinger om overvågningens ubegrænsede rækkevidde bygger på denne vrangforestilling. Alle perspektiver, der forstår at se noget som helst 'klart', er derimod altid socio-tekniske, partielle, transformerende og forbundne, når vi ser nærmere efter.

Gevinsten ved at forlade de idealtypiske metaforer er, set fra et akademisk synspunkt, blandt andet, at en større analytisk tålmodighed i forhold til overvågningsfænomener fremstår uomgængelig og passende. Og en sådan kan måske i bedste tilfælde også bevirke, at vi bliver bedre i stand til at lade os overraske af overvågningsfænomener. I forlængelse heraf kan gevinsten fra et kunstnerisk synspunkt være en større sensitivitet for overvågningens mange facetter. Her anviser Jill Magids "Surveillance Shoe | Legoland" muligheden for at etablere en frugtbar modstand. Hun iscenesætter sit objekt i samspil med en konkret form for overvågning, der er på spil i samtiden. Hendes overvågningssko tager derfor et skridt væk fra at kritisere overvågning på baggrund af idealtypiske forestillinger. Ligesom Latour viser Magid, at man i studier af overvågning med fordel kan møde den analytiske udfordring, der består i at læse specifikke overvågningssituationer på deres egne præmisser.

\section{LITTERATURLISTE}

Foucault, Michel. Overvågning og straf: fangslets fødsel. Frederiksberg: Det lille Forlag, 2002 [1975].

Gad, Christopher og Lone Koefoed Hansen. "Præventive Potentialer.” Slagmark, indleveret 2010.

Gad, Christopher og Casper Bruun Jensen. “On the Consequences of Post-Ant.” Science Technology \& Human Values 346 (2009).

- -.. "Philosophy of Technology as Empirical Philosophy - Examining Technological Scales in Practice.” New Waves in Philosophy of Technology. red. Selinger, Evan, Søren Riis and Jan-Kyrre Berg Olsen. Basingstoke \& New York: Palgrave Macmillan, 2008: 292-314.

Gad, Christopher og Peter Lauritsen. "Situated Surveillance - an Ethnography of Fisheries Inspection.” Surveillance ङ Society 71 (2009): 49-57.

Haggerty, Kevin D. "Tear Down the Walls: On Demolishing the Panopticon.” Theorizing Surveillance. The Panopticon and Beyond. Ed. Lyon, David. Portland: Willan Publishing, 2006: 23-45.

Hansen, Lone Koefoed "In the Shadow of the Cell-Phone". DAC - Digital Arts and Culture 2009.

Ed. Penny, Simon. UC Irvine, CA, 2009.

Latour, Bruno. Reassembling the Social: An Introduction to Actor-Network-Theory. Oxford: Oxford University Press, 2005. 
Latour, Bruno og Emilie Hermant. "Paris: Invisible City". 2006. 〈http://www.bruno-latour.fr/livres/ viii_paris-city-gb.pdf>.

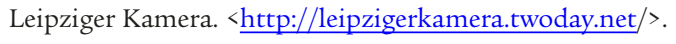

Leipziger Kamera og Space Hijackers. "Hijacking CCTV - Actions Speak Louder Than Words". 2008. 〈http://leipzigerkamera.twoday.net/topics/02+-+actions+speak+louder+than+words/>.

Lyon, David. Surveillance Studies: An Overview. Cambridge: Polity Press, 2007.

Magid, Jill. Surveillance Shoe | Legoland. 2000-7.

Mol, Annemarie. The Body Multiple: Ontology in Medical Practice. Durham: Duke University Press, 2002.

Orwell, George. 1984. København: Gyldendal, 1956 [1948].

Space Hijackers. 〈http://www.spacehijackers.co.uk/html/welcome.html〉. 